\title{
Open cast mining: threat to water quality in rural community of Enyigba in south-eastern Nigeria
}

\author{
C. C. Okolo' + T. D. T. Oyedotun ${ }^{2} \cdot$ F. O. R. Akamigbo ${ }^{3}$
}

Received: 30 December 2016 / Accepted: 10 October 2018 / Published online: 19 October 2018

(c) The Author(s) 2018

\begin{abstract}
Enyigba in south-eastern Nigeria is one of the agrarian communities facing water scarcity challenges. The open cast mining activities in the region are also compounding the water problems as a result of leakage of heavy metals that pollute the limited water resources. This study is conducted to document the current state of surface water contamination by heavy metals and its impact on domestic and agricultural uses. Thirty water samples were collected from five sources at both the upstream, middle stream and downstream of each of the selected sites. The heavy metals were analysed using the standard laboratory methods. Generally, the average concentrations of $\mathrm{As}, \mathrm{Cd}, \mathrm{Cu}, \mathrm{Pb}$ and $\mathrm{Zn}$ in the studied water bodies were 17.68, 4.30, 3.14, 0.05 and $35.57 \mathrm{mg} / \mathrm{l}$, respectively, which were above the WHO permissible limit. Contamination of water above WHO permissible limits with heavy metals in the surface waters, because of open cast mining, is considered a serious threat to both domestic and agricultural usage. The need for establishment of treatment facility, periodic monitoring of heavy metal levels, recycling plants and principal technologies to monitor the mine sites are hereby recommended.
\end{abstract}

Keywords Acid mine drainage $\cdot$ Contamination $\cdot$ Toxic metals $\cdot$ Water resources

\section{Introduction}

Water is an essential and highly scarce resource for human being whose demand has always been driven by population pressure and huge demands for water in meeting various anthropogenic needs (McDonald et al. 2011a, b; Oyedotun 2012; Böhmelt et al. 2014). Compounding the water challenge is climate change which affects not only the water availability but also quality, demand and use (Mouratiadou et al. 2016) with diverse implications beyond the water sectors alone (McDonald et al. 2011a, b). This is especially true of many communities in sub-Saharan Africa (SSA) as

\section{C. Okolo}

okolochukwuebuka@gmail.com;

okolo.chukwuebuka@mu.edu.et

1 Department of Land Resources Management and Environmental Protection, Mekelle University, P. O. Box 231, Mekelle, Ethiopia

2 Department of Geography, Faculty of Earth and Environmental Sciences (FEES), University of Guyana, P. O. Box 10 1110, Turkeyen Campus, Georgetown, Guyana

3 Department of Soil Science, University of Nigeria, Nsukka, Nigeria affirmed by the studies of Zhu and Ringler (2010), Oyedotun (2012), Asaba et al. (2013), Uguru (2014) and Scanlon et al. (2016). The report of UNEP (2008) stated that one-third of the African population now live in drought-prone areas, and almost all the SSA countries will experience water stress by 2025 . However, more population in SSA are noted to be without access to water in 2015 than those in 1990 (Scanlon et al. 2016), a continuous challenge that is yet to be abated more than 15 years into the new millennium in SSA countries. Currently, both the population and climate pressures have made the south-eastern Nigeria to face freshwater scarcity for agricultural and domestic uses (Okogbue and Ukpai 2013; Okolo 2014). Coupled with this is the contamination of the limited water resource by heavy metals because of open cast mining activities in the region (Nnabo 2016).

Open cast mining is the process of removing the vegetation and the use of heavy equipment and hard implements to mine a target mineral (Bagherpour and Tudeshki 2007; Ezeaku 2012), thus creating pits and dumps in the process leading to land degradation (Okolo et al. 2015). Heavy metal pollution of water bodies is caused when such metals as arsenic (As), silver (Ag), cobalt (Co), cadmium (Cd), lead (Pb) and zinc $(\mathrm{Zn})$ in excavated rock or in an open underground mine come in contact with water (SDWF 2010). Open cast

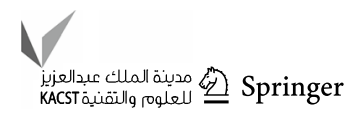


mining gives rise to acid rock drainage-a natural process whereby sulphuric acid is produced when sulphides in rocks are exposed to air and water (SDWF 2010; McCarthy 2011). Acid mine drainage (AMD) arises primarily when the mineral pyrite in rocks meets oxygenated water $(\mathrm{McCa}-$ rthy 2011). The acid produced is carried off the mine site by rainwater or surface drainage and deposited into water bodies or groundwater, thereby polluting them. Acid mine drainage (AMD) severely contaminates and degrades water quality, causing severe damages to aquatic life and making water virtually unusable and inimical to human health (Yang et al. 2016). Water pollution occurs when harmful substances are discharged into water bodies without provision of adequate treatment for the removal of harmful compounds, and/or when there is a significant change in its ability to support its biotic communities (Ezeaku 2012; Ascott et al. 2016) and this remains a major challenge in south-eastern Nigeria (Okolo 2014). In addition to over population, water pollution is another major global problem which requires continuous ongoing evaluation, systematic approach and revision of water resource policy at all levels (Haddis et al. 2014; Waseem et al. 2014; Seth et al. 2016). Water pollution has potential toxic effects on living organisms (Segura et al. 2006; Bodrud-Dozaa et al. 2016) and critically degrades aquatic system (Suresh et al. 2012; Tang et al. 2013). Heavy metal contamination of streams, river and groundwater ecosystems remains a global environmental problem, and in almost all cases, the effect is damaging to natural biological communities, individual species and wider ecosystem populations (Sekabira et al. 2010). Of the wide diversity of contaminants challenging the usability of water resources, heavy metals remain of remarkable concern because of their toxicity, persistence and bioavailability (Montouris et al. 2002; Wu et al. 2016) and their strong toxicity even at low concentrations (Marcovecchio et al. 2007). Heavy metals are persistent environmental contaminants and are at least five times denser than water (SDWF 2010). As such, they cannot be metabolized by the body but are rather stable and bioaccumulative (Sekabira et al. 2010). These toxic metals are sometimes passed up through the food chain to humans (Fakayode and Olu-Owolobe 2003). These metals include mercury, nickel, lead, arsenic, cadmium, aluminium, platinum and copper (in their metallic and ionic form) (Alloway 1995; Kabata-Pendias and Pendias 2001; SDWF 2010). There are indications that heavy metal contamination is among the leading causes of deaths globally after ischaemic heart disease, stroke, cancer and lower respiratory infections (Goel 2006; Hogan 2010; WHO 2014). Heavy metal contamination has been observed to account for deaths of more than 14,000 people daily (Goel 2006). Apart from the acute problems of water pollution reported in developing countries (Nigeria inclusive), developed nations are not also exempted from this environmental phenomenon challenging our ubiquitous resource, water (Ascott et al. 2016). In addition to anthropogenic activities, natural incidences such as volcanoes, algae, blooms, storms and earthquakes equally cause major alterations in water quality and the ecological status of water which are inimical to human health.

Ebonyi State in south-eastern Nigeria is an agrarian state (Okolo et al. 2013) and has a severe problem of reduced quality of portable water (Okogbue and Ukpai 2013). The inhabitants of Enyigba (in Ebonyi State, south-eastern Nigeria), which is one of the major communities where mining is heavily done in the state, are historically farmers who make use of the surrounding water bodies for irrigation and domestic purposes (Nnabo 2015a, 2016). Previous studies at the study location focused on the impact of heavy metal contamination on abandoned mine pits, underground water sources, rivers, streams and artificial lakes (Ezeh 2007; Ezeh and Anike 2009; Nnabo 2015b, c, 2016), thus neglecting the active mine pits which usually serve as source of irrigation to the local farmers during periods of water scarcity.

Indeed, mineral extraction and extractive industries have increased enormously in the last sixty (60) years in response to increasing demands for more energy and primary commodities (Matinez Alier et al. 2003; Krausmann et al. 2009); the relaxation or inobservance of mining laws (Bridge 2004; Arboleda 2015; Basu et al. 2016); and different technological innovations and techniques (Watts 2015). With the increase in mining activities are the increases in environmental problems, communal conflicts and resistance (e.g. Castells 2013; Martinez Alier et al. 2014; Kirsch 2014; Gamu et al. 2015; Conde and Le Billon 2017). Interest and studies on impacts of mining activities on communities have been increasing during the last few years (e.g. Khan et al. 2013; Arsel et al. 2016; Northey et al. 2016; Engels and Dietz 2017; Andrews 2018; Askland 2018; Mhlongo, et al. 2018; Rakotondrabe et al. 2018); however, not all the impacts of mining on rural communities are widely reported except those that buttress the importance of such activities to the income of the communities or that of the economic developments of nations involved (e.g. Bury, 2007; Bashwira et al. 2014; Seccatore et al. 2014; Lghoul et al. 2014; Achtenberg 2016; Brain 2017; Louw and Marais 2018). Like most developing countries, Nigeria is not immune to the real and potential threats of small-scale mining activities on the aquatic and terrestrial environments (air, flora, fauna, soils and water resources, etc.), (Ibetao and Okoye 2010), but most of the investigations have focused on the impacts of open pit mining that focused on surface water with emphasis on other parts of Nigeria (e.g. Ayodele and Abubakar 2001; Ameh and Akpah 2011; Ogwueleka 2015; Taiwo and Awomeso 2017) and in this location on the abandoned pit (e.g. Ezeh and Anike 2009; Nnabo 2015b; c; 2016). The overarching aim of this study is to investigate the impacts 
of open cast active mining on surface water quality, which is the main source of irrigation and domestic usages in Enyigba, a rural community in the south-eastern Nigeria. The specific objectives are to assess selected physical and chemical characteristics of surface water sources in the study area and to ascertain the toxicity levels of the water using WHO standard.

Recently, Ngele et al. (2015) in a similar study compared the contamination levels in an active mine pit and a nearby pond in Enyigba mine district in south-eastern Nigeria, without considering other surface water bodies in the area, which is the gap this study intends to cover. Activities of small-scale miners have left behind numerous artificial ponds and pits, which form sources of drinking, agricultural and other domestic purposes for the inhabitants, especially during periods of water scarcity. Thus, water available within the Enyigba mine vicinity might have been contaminated by potentially toxic elements from tailings emanating from mining activities through wind and water within the vicinity of the mine area. Hitherto, there have been limited scientific studies to assess the extent of heavy metal contamination in the surface water as a result of the defunct and ongoing small-scale mining activities in this location, hence another justification for this study. The research finding is hoped to document the growing interest in the rising number of rural environmental problems, especially water quality concerns, that are linked to small-scale open cast mining and contribute to the growing literary knowledge of this issue in south-eastern Nigeria, which is hoped to help relevant stakeholders in environmental land use planning and water management.

\section{Materials and methods}

\section{The study area}

The study was conducted at Enyigba in Abakaliki Local Government Area of Ebonyi State, Nigeria. Enyigba is $14 \mathrm{~km}$ southeast of Abakaliki in Southeast Nigeria. The area of study lies between latitudes $6^{\circ} 07^{\prime} \mathrm{N}$ and $6^{\circ} 12^{\prime} \mathrm{N}$ and longitudes $8^{\circ} 05^{\prime} \mathrm{E}$ and $8^{\circ} 10^{\prime} \mathrm{E}$ in the derived savanna vegetation zone (Fig. 1).

The area experiences bimodal pattern of rainfall (April-July) and (September-November) with short dry spell in August normally called "August break". The total mean annual rainfall is between 1700 and $2000 \mathrm{~mm}$. At the onset of rainfall, it is torrential and violent, sometimes lasting for $1-2 \mathrm{~h}$. The minimum and maximum temperatures are $27{ }^{\circ} \mathrm{C}$ and $31{ }^{\circ} \mathrm{C}$, respectively, while relative humidity is in the range of 60-80\% (ODNRI, 1989). Population of Enyigba community (suburb of Abakiliki) is estimated to be 8000 from the 79,280 population of the Abakaliki (capital of Ebonyi State, south-eastern Nigeria) inhabitants according to 2006 Population Census (Hoiberg 2010; Oriji 2011). The dry harmattan wind from Sahara Desert prevails in the dry season. In the rainy season, the significant wind is the marine wind from the Atlantic Ocean. The soil in this area belongs to the order Ultisol (FDALR 1985). The relief of the

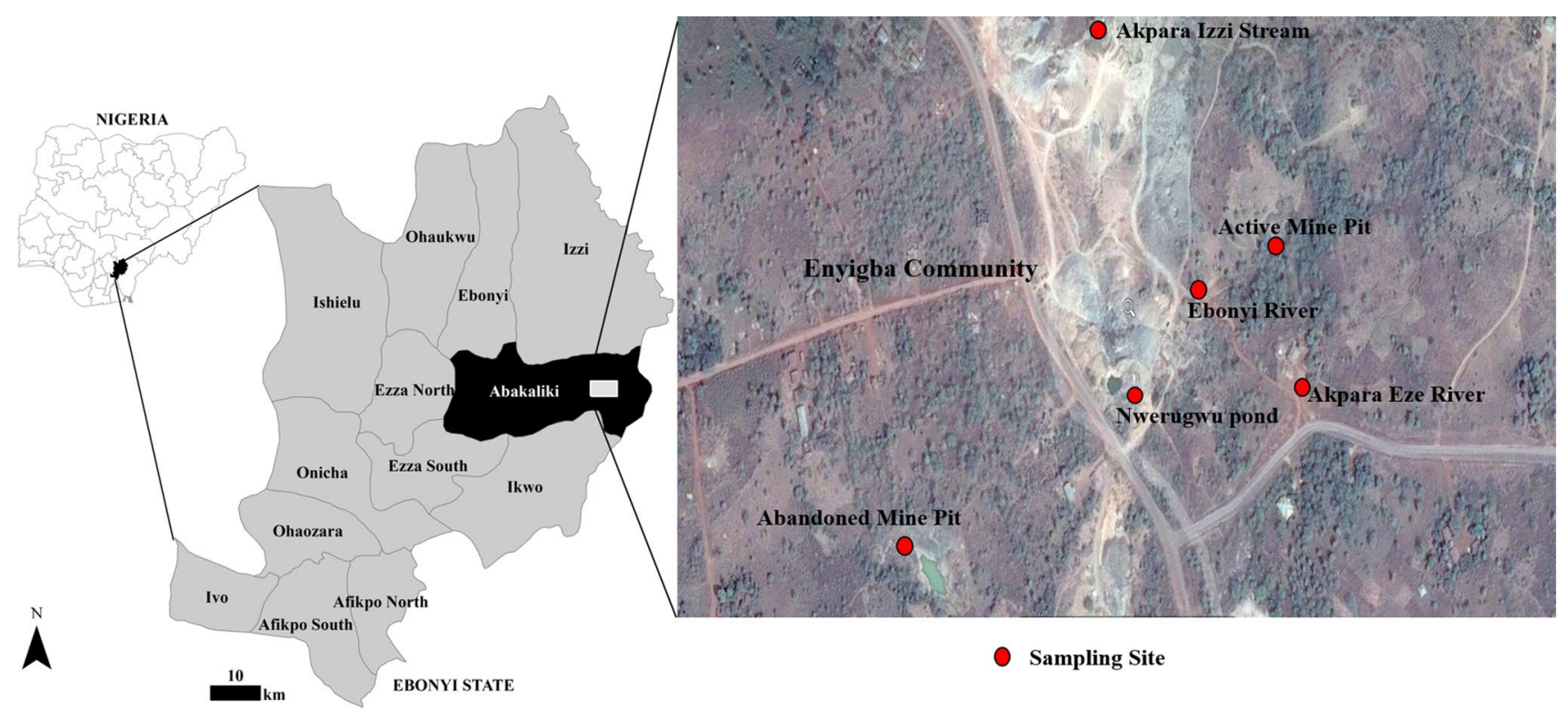

Fig. 1 The map of Enyigba community showing the sampling sites (insets: map of Nigeria showing Ebonyi State and map of Ebonyi State showing location of Enyigba community: The data for the map were extracted from the DIVA-GIS database (http://www.diva-gis. org/), @1995-1998, LizardTech, Inc.; Enyigba map-courtesy of Mapcarta @ http://mapcarta.com/es/17032198/Mapa) 
area is undulating but with isolated hillocks that rise up to $200 \mathrm{~m}$ above sea level (Obiora et al. 2016). The vegetation of the area is Parkland, characterized mainly with grasses and shrubs which is derived savannah (Obiora and Umeji 2004; Obiora et al. 2016). This consists of dark sandy shales, with fine-grained micaceous sandstone and mudstone. The lithology of the area comprises of rocks and shales belonging to the Asu River Group of the Albian Cretaceous sediments, while the sedimentary rocks are predominantly black calcareous shale with irregular intercalation of siltstone. The group is known to be associated with $\mathrm{Pb}-\mathrm{Zn}$ mineralization with shales which are often calcareous and pyritic (Ezeh and Anike 2009), and the rocks are extensively fractured, folded and faulted, while the geology and mineral resources are the main factors responsible for the availability of heavy metals (Nnabo 2015a). Surface drainage in the area is quite undulating and irregular with several ephemeral ponds, streams and rivers which always dry up with the advent of raining season.

\section{Water sampling and analysis}

Three water samples (top stream, middle stream and bottom stream) were collected in duplicates from five sources to give a total of thirty water sample readings. The surface water samples were collected from the following sources within Enyigba mining community, namely Ebonyi river, Akpara Izzi, Nwerugvu pond, active mine pit and abandoned mine pit with their coordinates shown in Fig. 2. The sources were randomly selected without consideration of distance from mine pits and depict the major sources of water in Enyigba community for both domestic and agricultural purposes. The upper, middle and bottom positions of the surface water sources served as up-mid and downstream, thus representing the replicates for each source. The temperature of the water samples was taken immediately at the sites of collection using a simple thermometer calibrated in degree Celsius (Rasool et al. 2016). Insoluble matter was removed from the samples by filtration using the Whatman filter papers number 42 (Kramer 1994; Eaton et al. 1995). Total dissolved solid (TDS) was determined in situ by using HQD Hach Lange multiparameter metres (Manchester, UK) in line with the procedure recommended by Kribek (2013) for the UNESCO-SIDA-sponsored Abandoned Mines Project in sub-Saharan African countries. The $\mathrm{pH}$ of the water samples was measured electronically on direct-reading $\mathrm{pH}$ meter using a glass electrode with a saturated potassium chloride calomel reference electrode (Mclean 1982) at the Soil Science Research Laboratory, University of Nigeria. Tight-capped high-quality polyethylene bottles were used for sample storage. Prior before use, the bottles were washed by distilled deionized water and rinsed overnight in $10 \%$ $(v / v)$ nitric acid and later with the sample surface water before filling. The method followed by Assubaie (2015) was adopted to prevent precipitation of metals and biological growth, by the addition of few drops of concentrated nitric acid to samples to obtain $\mathrm{pH}$ around 2. Thereafter, samples were immediately transported to the laboratory of the Department of Soil Science, University of Nigeria, Nsukka, in iceboxes and stored at $4{ }^{\circ} \mathrm{C}$ up to analysis (after Tang et al. 2013). Standard laboratory methods were followed for the determination of heavy metals surface water quality parameters (APHA-AWWA-WPCF 1998). The concentrations of heavy metals in the water samples, namely arsenic (As), copper $(\mathrm{Cu})$, lead $(\mathrm{Pb})$ and zinc $(\mathrm{Zn})$, were determined by inductively coupled plasma-optima emission spectrometry (ICPOES, Optima 5300DV, PerkinElmer Instruments, USA), while cadmium $(\mathrm{Cd})$ was determined by atomic absorption spectrometer (AAnalyst 800, PerkinElmer Instruments, USA) under standard operating laboratory conditions. All the samples from the surface waters were analysed, and the results of all parameter were the average of the three surface water samples from each source.

\section{Results and discussion}

In all the surface water samples, the mean $\mathrm{pH}$ values ranged from 5.5 in active mine pit to 6.9 in abandoned mine pit and Ebonyi River (Table 1). All the surface water sources have $\mathrm{pH}$ mean value within the WHO permissible limit (6.5-8.5) with the exception of active mine pit (5.5). The relatively low $\mathrm{pH}$ of active mine pit may be due to dissolution and decomposition of sulphide minerals including pyrite in mine waste dumps tailings (Ezeh and Anike 2009). Expectedly, the low $\mathrm{pH}$ especially in active mine pit implies that AMD has been produced. Similar results of low $\mathrm{pH}$ in surface waters have been reported by Nnabo (2015b) in the same study area.

\section{Arsenic (As)}

Arsenic (As) mean concentration in the study area ranged from $0.02 \mathrm{mg} / \mathrm{l}$ to $61.44 \mathrm{mg} / \mathrm{l}$. The highest mean concentration of As $(61.44 \mathrm{mg} / \mathrm{l})$ was detected at Nwerugvu pond. (Nwerugvu pond is not a flowing water body and is closer to an active mine pit (Mkpoda Ugwvu) which is a possible source of contamination (Okolo et al. 2015).) The lowest mean concentration of $0.02 \mathrm{mg} / \mathrm{l}$ was detected at active mine pit (Fig. 2c and e). The highest As concentration recorded at the area of study is lower than the upper limit of $91 \mathrm{mg} / \mathrm{l}$ from the normal range of 30-91 mg/l in a study of water quality in Bestari Jaya ex-mining area, Peninsular Malaysia (Ashraf et al. 2010), and much higher than the range of $0.01-2.50 \mathrm{mg} / \mathrm{l}$ in a study of surface water contamination by heavy metals from Enyigba $\mathrm{Pb}-\mathrm{Zn}$ mine district, 
Fig. 2 - Water sources: a Akpara Izzi stream, one of the tributaries of Ebonyi River $\mathbf{b}$ sampled for this study. Ebonyi River is the major source of water for farming and domestic usages of the inhabitants of Enyigba, Ebonyi State of Nigeria. c Example of active mine pit showing the wooden ladder being used for mining operations, the blue pipe being used for draining water from the mine pit into the adjoining farmlands, Akpara Izzi stream and other streams within the vicinity of the mining sites. $\mathbf{d}$ and $\mathbf{f}$ examples of abandoned mine pits filled with water and heaps of fine-grained wastes (tailings) surrounding the pit. e Example of dry active mine pit with wooden ladder used for mining operations
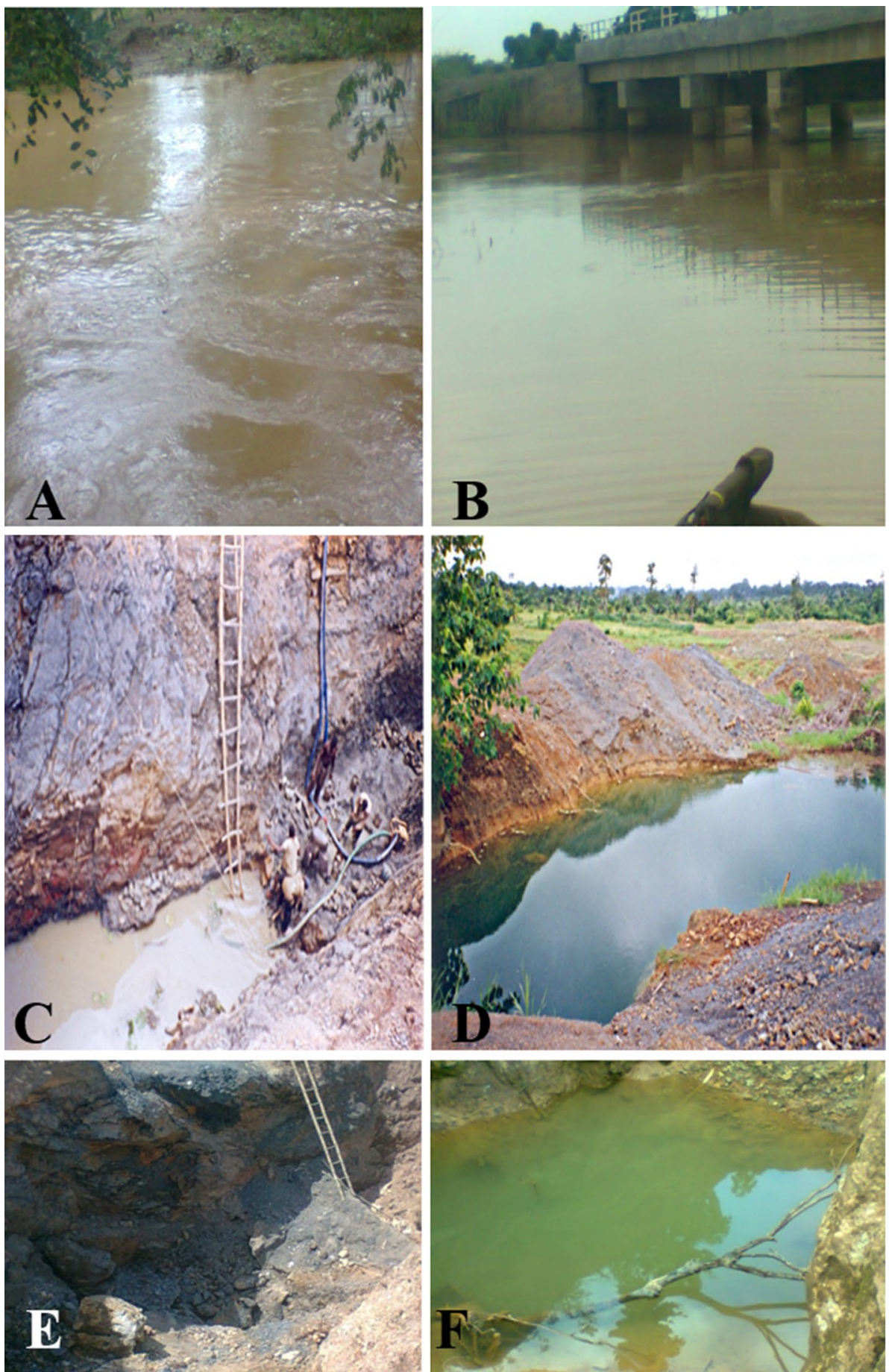

south-eastern Nigeria (Nnabo 2016). The mean range of $0.02-61.44 \mathrm{mg} / \mathrm{l}$ concentration of As in the present study is higher than critical water total concentration of $0.01 \mathrm{mg} / 1$ (WHO 2011). This range of 0.02-61.44 mg/l mean concentration of As is 2-6 times above the WHO (2011) limit for water quality (Table 1). In contrast with results of the present study, O'Niell et al. (2015) in a study of contaminants in surface water and sediments near the Tynagh silver mine site, County Galway, Ireland, reported that the concentrations of As in all water samples studied were below limits of detection (LOD). Elevated levels of As and Mn have been reported in waters nearby the mine wastes generated from mining of $\mathrm{Ba}-\mathrm{Pb}-\mathrm{Zn}$ quartz veins at Segura area, central Portugal (Antunes et al. 2008). Higher As values above the WHO permissible limits have also been reported by Omaka et al. (2017) in water samples collected from different parts of south-eastern Nigeria. These elevated values of As concentration in all the water sources in the study area make 
Table 1 Mean values of heavy metal concentration (mg/l) of $\mathrm{As}, \mathrm{Cd}, \mathrm{Cu}, \mathrm{Pb}$ and $\mathrm{Zn}$ in surface water/WHO permissible limits

\begin{tabular}{lllrlrrrrr}
\hline Sample location/WHO permissible limit & Elevation $(\mathrm{m})$ & ${ }_{\mathrm{p}} \mathrm{H}$ & $\mathrm{TDS}$ & $\mathrm{T}\left({ }^{\circ} \mathrm{C}\right)$ & $\mathrm{As}(\mathrm{mg} / \mathrm{l})$ & $\mathrm{Cd}(\mathrm{mg} / \mathrm{l})$ & $\mathrm{Cu}(\mathrm{mg} / \mathrm{l})$ & $\mathrm{Pb}(\mathrm{mg} / \mathrm{l})$ & $\mathrm{Zn}(\mathrm{mg} / \mathrm{l})$ \\
\hline Abandoned pit & 49.1 & 6.9 & 120 & 29 & 7.49 & 1.28 & 3.05 & - \\
Active pit & 58.7 & 5.5 & 40 & 29 & 0.02 & 4.77 & 4.77 & 0.07 & 27.46 \\
Akpara Izzi stream & 44.9 & 6.7 & 90 & 29 & 11.99 & 2.33 & 2.51 & - & 31.38 \\
Nwerugvu pond & 61.2 & 6.5 & 50 & 29 & 61.44 & 2.13 & 3.56 & 0.03 & 65.38 \\
Ebonyi River & 33.7 & 6.9 & 110 & 27 & 7.49 & 11.01 & 1.84 & - & 26.15 \\
WHO permissible limit (2011) & & $6.5-8.5$ & 500 & $<15$ & 0.01 & 0.003 & 2.00 & 0.01 & 5.00 \\
\hline
\end{tabular}

$T D S$ total dissolved solid, $A s$ arsenic, $C d$ cadmium, $C u$ copper, $P b$ lead, $Z n$ zinc, T $\left({ }^{\circ} \mathrm{C}\right.$ ) temperature in celsius, - traces (not detected)

the water unsafe for human and animal consumption. High As concentration may have been associated with the mining activities in the area.

\section{Cadmium (Cd)}

Cadmium mean concentration in the sampled surface waters ranged from 1.28 to $11.01 \mathrm{mg} / \mathrm{l}$ (Table 1) and exceeds the WHO (2011) drinking water limit of $0.003 \mathrm{mg} / \mathrm{l}$ (Table 1). The highest $\mathrm{Cd}$ concentration $(11.01 \mathrm{mg} / \mathrm{l})$ was detected at Ebonyi River and is 4 times above the WHO (2011) drinking water limit. The high concentration of $\mathrm{Cd}$ in Ebonyi River (Fig. 2b) could be attributed to the transportation and redeposition in downstream of mobilized contaminants emanating from mine tailings. Through this, contaminants are introduced into the stream ecosystem, which are tributaries of the Ebonyi River. On the other hand, the source of $\mathrm{Cd}$ could be from phosphate fertilizer that is usually used in that area (Chukwuma, 1994) as reported in Okolo (2014). In the area of study, this is of serious concern because Ebonyi River is significant in the region as a major source of water for irrigation, municipal water supply and a major source of fish, molluscs and crustaceans which serve as a major source of food in the area. Similarly, as observed by Navarro et al. (2008), $\mathrm{Pb}, \mathrm{Zn}$ and $\mathrm{Cd}$ along this water body may have originated from sulphide minerals within the mine area. Assubaie (2015) reported a much lower Cd range of 0.009-0.013 mg/l in an assessment of the levels of some heavy metals in water in Alahsa Oasis farms, Saudi Arabia, with analysis by atomic absorption spectrophotometry compared to Cd levels of the present study. The results of the present study indicate contamination of the water bodies with $\mathrm{Cd}$ which is consistent with previous studies in the study location (Ezeh and Anike 2009; Nnabo 2015a, b, c, 2016) and other parts of southeastern Nigeria (Omaka et al. 2017).

\section{Copper (Cu)}

The mean concentration of $\mathrm{Cu}$ in the sampled surface water was in the range of $1.84 \mathrm{mg} / \mathrm{l}-4.77 \mathrm{mg} / \mathrm{l}$ (Table 1). The highest concentration of $4.77 \mathrm{mg} / \mathrm{l}$ was detected at active mine pit and the lowest concentration of $1.84 \mathrm{mg} / \mathrm{l}$ at Ebonyi River (Table 1). The concentration of $\mathrm{Cu}$ in surface water throughout the sampled water bodies exceeds the WHO (2011) drinking water limit of $2 \mathrm{mg} / \mathrm{l}$ (Table 1) with the exception of Ebonyi River which recorded the lowest concentration of $1.84 \mathrm{mg} / \mathrm{l}$. The range of $1.84 \mathrm{mg} / \mathrm{l}-4.77 \mathrm{mg} / \mathrm{l}$ in the present study is higher than the range of $0.004-0.026 \mathrm{mg} / \mathrm{l}$ as reported by Ezeh and Anike (2009) in the samples of surface waters from the same Enyigba mine district and also higher than the rate of 0.011-0.017 mg/l reported by Assubaie (2015) in an assessment of the levels of some heavy metals in water in Saudi Arabia. High-level $\mathrm{Cu}$ in the study area with exception of Ebonyi River could be attributed to the possible contribution from anthropogenic sources, with the industrial and/or domestic activities as another potential source of contribution by $\mathrm{Cu}$ in the environment of the study area. Nnabo (2016) in a study of surface water contamination by heavy metals from Enyigba $\mathrm{Pb}-\mathrm{Zn}$ mine district, south-eastern Nigeria, reported a $\mathrm{Cu}$ concentration range of $0.01-1.22 \mathrm{mg} / \mathrm{l}$ which is lower than the range of the present study.

\section{Lead $(\mathrm{Pb})$}

The concentration of $\mathrm{Pb}$ throughout the sampled surface water exceeds the WHO (2011) drinking water limit of $0.01 \mathrm{mg} / \mathrm{l}$ (Table 1). Nwerugvu pond recorded the lowest mean concentration $(0.032 \mathrm{mg} / \mathrm{l})$, while active mine pit gave the highest mean concentration $(0.068 \mathrm{mg} / \mathrm{l})$ which are 3 and 7 times above the WHO (2011) drinking water limit, respectively. Lead was not detected in Akpara Izzi (Fig. 2a), Ebonyi River (Fig. 2b) and abandoned pit (Fig. 2d). However, the inability to detect $\mathrm{Pb}$ in the aforementioned water bodies does not mean that it is meeting the recommended drinking water standard of $0.01 \mathrm{mg} / \mathrm{l}$. Thus, the inability to detect $\mathrm{Pb}$ does not mean $\mathrm{Pb}$ is not in the water bodies, but rather it simply shows that it could be present in amounts below the detection limit (DL) of our analytical instrument. 
The reasons for this are still unclear, and further investigations are needed.

\section{Zinc (Zn)}

Zinc mean concentration in the studied surface water bodies was all above the WHO drinking water limit of $5.00 \mathrm{mg} / \mathrm{l}$ and ranged from 26.15 to $65.38 \mathrm{mg} / \mathrm{l}$ (Table 1). The lowest $\mathrm{Zn}$ mean concentration of $26.15 \mathrm{mg} / \mathrm{l}$ is 5 times above the WHO limit, while the highest $\mathrm{Zn}$ mean concentration of $65.15 \mathrm{mg} / \mathrm{l}$ is 13 times above the WHO limit. Nwerugvu pond recorded the highest $\mathrm{Zn}$ mean concentration of $65.38 \mathrm{mg} / \mathrm{l}$, while Ebonyi River recorded the lowest $\mathrm{Zn}$ mean concentration of $26.15 \mathrm{mg} / \mathrm{l}$. The mean range of $26.15-65.38 \mathrm{mg} / \mathrm{l}$ recorded in the present study is far below the range of $86-132 \mathrm{mg} / \mathrm{l}$ reported by Ashraf et al. (2009) in ex-mining area of Bestari Jaya, Peninsular Malaysia, but very much higher than the range of $0.006-0.023 \mathrm{mg} / \mathrm{l}$ with mean concentration of $0.01 \mathrm{mg} / \mathrm{l}$ reported by Ezeh and Anike (2009) in surface waters of Enyigba mining district of Ebonyi State. The highest mean $\mathrm{Zn}$ concentration of $65.38 \mathrm{mg} / \mathrm{l}$ recorded at Nwerugvu pond could equally be associated with human activities such as the use of chemical- and zinc-based fertilizers (zinc sulphate hepta fertilizer $98 \% \mathrm{ZnSO}_{4} \cdot 7 \mathrm{H}_{2} \mathrm{O}$ and zinc EDTA fertilizers) by farmers in the area (Nweke et al. 2008). Similar to results of this present study, Omaka et al. (2017) equally reported significantly higher values of $\mathrm{Zn}$ concentration in water samples from different parts of south-eastern Nigeria. The higher concentration of $\mathrm{Zn}$ in the present study coupled with its high mobility rate poses a serious health challenge in water bodies of the study area, where mining operations and deposits of sphalerite may contribute to higher concentrations. In general, the distribution of the heavy metals in the surface waters is $\mathrm{Zn}>\mathrm{As}>\mathrm{Cd}>\mathrm{Cu}>\mathrm{Pb}$. Therefore, the metals with the highest and lowest mean levels are zinc $(65.38 \mathrm{mg} / \mathrm{l})$ and $\mathrm{Pb}(0.032 \mathrm{mg} / \mathrm{l})$, respectively.

Generally, all the water bodies analysed showed higher concentrations of heavy metals above the WHO permissible, which is a strong indication of pollution as a result of some defunct and the ongoing open cast mining within the vicinity. The observed high concentrations of heavy metals in the sampled water bodies, especially in Nwerugvu pond, Akpara Izzi stream and Ebonyi River in the long run, may have a direct negative health impact (damaged or diminished mental and central nervous function, and also, lower energy level) when used as drinking water by both humans and livestock. Also, the water from ponds and mine pits when pumped with pipes and sprayed on the surrounding farm lands could expose the surface soils and agricultural crops to high heavy metal contamination (Fakayode and Olu-Owolobe 2003). This will eventually lead to high metal accumulation in crops and leaching of these heavy metals to ground water, thus a great threat to human health.

\section{Total dissolved solid (TDS)}

TDS is a direct measure of all the organic and inorganic dissolved particles in water. The highest TDS value $(120 \mathrm{mg} / \mathrm{l})$ was recorded in abandoned mine pit, and this was possibly caused by high solids loading in the abandoned mine pit. The TDS values recorded in this study were below the WHO permissible limit of $500 \mathrm{mg} / \mathrm{l}$ (Table 1), but higher than the value $(50.7 \mathrm{mg} / \mathrm{l})$ recorded in polluted stream water in an open cast mining district of Nasarawa State, Nigeria (Ezeaku 2012) and much lower than the elevated values of 653 and $384 \mathrm{mg} / \mathrm{l}$ recorded in mechanic village and Chanchanga river, respectively, in Niger State, Nigeria (Tsado et al. 2014). The range of TDS values recorded in this present study is similar to the TDS values $(<500 \mathrm{mg} / \mathrm{l})$ reported by Omaka et al. (2017) in selected parts of south-eastern Nigeria. High TDS influences virtually all other qualities of water, for example hardness, taste and corrosion properties. Low TDS values in this study simply imply that the water can be generally treated by conventional method although it may reduce basic utility of water for domestic (cooking and drinking) and irrigation purposes. Notably, TDS is generally negatively charged and therefore is more susceptible to heavy metalloids, reducing their concentrations in water (Seth et al. 2016). Olajire and Imeokparia (2001) reported that high levels of TDS in irrigated water may be an indication of seepage of filthy surface waters into the ground water and soil beneath the ground surface as water percolates through them. Increase in dissolved solids in surface and irrigation water affects not only the soil efficiency but also the crops growth and yields (Abdullahi et al. 2010). Cropping activities were visible in the study area, and high levels of heavy metals and TDS may pose a threat to sustainable agricultural production and may also be inimical to human health.

The mean temperature ranged between 27 and $29^{\circ} \mathrm{C}$ and was above the WHO (2011) permissible limit of $<15{ }^{\circ} \mathrm{C}$. The high temperature of surface water samples from active mine pit, abandoned pit, Akpara Izzi and Nwerugvu pond could be attributed to the increase in rate of chemical reaction. The temperature range in the study area is comparable to the $28{ }^{\circ} \mathrm{C}$ reported by Oparaocha et al. (2010) in assessing the quality of drinking water sources in south-eastern Nigeria. 


\section{Conclusion}

This study has shown that open cast mining evidently impacted on the water usage, thus leading to heavy metal contamination of $\mathrm{Pb}, \mathrm{As}, \mathrm{Zn}, \mathrm{Cu}$ and $\mathrm{Cd}$. The report of this study on heavy metal contamination of surface water bodies such as river, stream, pond, active mine pit and abandoned mine pit has been shown here to impact the water properties at Enyigba south-eastern Nigeria. In all the water bodies analysed, heavy metals were found to be above WHO (2011) permissible limits. Therefore, based on high levels of reported heavy metal in the water bodies, there is urgent need for holistic detailed research comprising soil, crop, water and biodiversity research of the Enyigba mine district to ensure environmental and agricultural sustainability.

Finally, the primary water pollution problem facing the inhabitants of the area is the lack of clean drinking water devoid of substances inimical to human health. Thus, concerted efforts should be made by State, Local and Federal Governments to ensure access to safe drinking water for the inhabitants of Enyigba community through adequate provision of water treatment and observations of the recommendations aforementioned above.

The study here further revealed that high heavy metal concentrations in water bodies above permissible limits can result in human health hazard and probable contamination of the food chains wherever open cast mining activities are undertaken in anywhere in the world without adequate check.

\section{Recommendation}

More so, some heavy metals are naturally occurring ( $\mathrm{Pb}, \mathrm{Zn}$ and As are stored in some rocks); hence, we recommend further studies with the use of principal component analysis to specifically identify various sources of contamination apart from the mining operations in the study area. It is hereby recommended that five principal technologies used to monitor and control water flow at mine sites, as suggested by the International Network for Environmental Compliance and Enforcement (INECE) URL, be applied: diversion systems, containment ponds, groundwater pumping systems, subsurface drainage systems and subsurface barriers.

Due to high concentration of heavy metals in the sampled water bodies, there is urgent need for construction of adequate and effective impoundments or dams designed to hold the tailings and mine water emanating from the mine pits and perform a number of functions, including treatment functions and recycling. More so, there is need for regular and effective periodic monitoring of soil and surface water quality so as to ensure that the standards of heavy metal constituents as set by WHO are not exceeded. Also, seasonal assessment of the surrounding water bodies (during rainy and dry seasons) is highly recommended and this will equally add to existing knowledge with regard to seasonal variations in levels of heavy metal concentration in mine sites.

Acknowledgements The authors are grateful to the Laboratory Staff of the Department of Soil Science, University of Nigeria, Nsukka, Nigeria. The technical and logistics support of Dr. Okechukwu Pius Aghamelu of the Geology Programme, Department of Physics/Geology/Geophysics, Alex Ekwueme Federal University, Ndufu-Alike, Ikwo, Ebonyi State, Nigeria, is highly appreciated and gratefully acknowledged. The anonymous reviewers whose vital comments helped in improving the quality of this article are also appreciated.

Open Access This article is distributed under the terms of the Creative Commons Attribution 4.0 International License (http://creativeco mmons.org/licenses/by/4.0/), which permits unrestricted use, distribution, and reproduction in any medium, provided you give appropriate credit to the original author(s) and the source, provide a link to the Creative Commons license, and indicate if changes were made.

\section{References}

Abdullahi AS, Funtua II, Dewu BBM, Alagbe SA (2010) Study of suitability of ground water for household and irrigation purposes in parts of Adamawa State, Northeastern Nigeria. Int Arch Appl Sci Tech 1(2):48-56

Achtenberg E (2016) What's behind Bolivia's cooperative mining wars? NACLA report on the Americas. http://nacla .org/blog/2016/11/23/what\%E2\%80\%99s-behind-boliv ia\%E2\%80\%99s-cooperative-mining-wars. Accessed 09 June 2018

Alloway BJ (1995) Heavy metals in soils. Chapman and Hall, Glasgow

Ameh EG, Akpah FA (2011) Heavy metal pollution indexing and multivariate statistical evaluation of hydrogeochemistry of River PovPov in Itakpe Iron-Ore mining area Kogi State, Nigeria. Adv Appl Sci Res 2:33-46

Andrews N (2018) Land versus livelihoods: community perspectives on dispossession and marginalization in Ghana's mining sector. Resour Policy. https://doi.org/10.1016/j.resourpol.2018.05.011

Antunes IM, Neiva A, Silva M (2008) Environmental contamination associated with some abandoned mines in Central Portugal. www.imwa.info/docs/imwa-2008/IMWA2008_078.Antunes.pdf

APHA-AWWA-WPCF (1998) American Published Health Association, American Water Association, Water Pollution Federation 1998. Standard methods for the examination of water and wastewater, 20th edn. Washington D.C

Arboleda M (2015) Financialization, totality and planetary urbanization in the Chilean Andes. Geoforum 67:4-13

Arsel M, Hogenboom B, Pellegrini L (2016) The extractive imperative and the boom in environmental conflicts at the end of the progressive cycle in Latin America. Extract Ind Soc 3(4):877-879

Asaba RB, Fagan GH, Kabonesa C, Mugumya F (2013) Beyond distance and time: gender and the burden of water collection in rural Uganda. J Gend Water 2(1):31-38

Ascott MJ, Gooddy DC, Lapworth DJ, Staurt ME (2016) Estimating the leakage contribution of phosphate dosed drinking water to environmental phosphorus pollution at the national-scale. Sci Total Environ. https://doi.org/10.1016/j.scitotenv.2015.12.121 
Ashraf MA, Maah MJ, Yusoff IB (2010) Study of water quality and heavy metals in soils and water of ex-mining area Bestaria Jaya, Peninsular Malaysia. Int J Basic Appl Sci 10(3):7-27

Askland HH (2018) A dying village: mining and the experiential condition of displacement. Extr Ind Soc 5:230-236

Assubaie FN (2015) Assessment of the levels of some heavy metals in water in Alahsa Oasis farms, Saudi Arabia, with analysis by atomic absorption spectrophotometry. Arab J Chem 8:240-245

Ayodele JT, Abubakar MB (2001) Trace metal levels in Tiga Lake, Kano, Nigeria. Trop Environ Res 3:230-237

Bagherpour R, Tudeshki H (2007) Material handling in world-wide surface mines. Aggreg Int 5:10-14

Bashwira MR, Cuvelier J, Hilhorst D, Van der Haar G (2014) Not only a man's world: women's involvement in artisanal mining in eastern DRC. Res Policy 40:109-116

Basu D, Bauthéac O, Laha AK (2016) Financialization and commodity price volatility: the case of metals. March 4 working paper. University of Strathclyde, Glasgow

Bodrud-Dozaa MD, Towfiqul Islamb ARM, Ahmeda F, Dasd S, Sahae N, Safiur Rahmanf M (2016) Characterization of groundwater quality using water evaluation indices, multivariate statistics and geostatistics in central Bangladesh. Water Sci 30:19-40

Bohmelt T, Bernauer T, Buhaug H, Gleditsch NP, Tribaldos T, Wischnath G (2014) Demand, supply, and restraint: determinants of domestic water conflict and cooperation. Glob Environ Change 29:337-348

Brain KA (2017) The impacts of mining on livelihoods in the Andes: a critical overview. Extr Ind Soc 4:410-418

Bridge G (2004) Mapping the bonanza: geographies of mining investment in an era of neoliberal reform. Profess Geogr 56:406-421

Bury J (2007) Livelihoods, mining and peasant protests in the Peruvian Andes. J Lat Am Geogr 1(1):1-19

Castells M (2013) Networks of outrage and hope: social movements in the internet age. Wiley, Hoboken

Chukwuma C (1994) Evaluating Baseline data for trace elements, $\mathrm{pH}$, organic matter content and bulk density in agricultural soils in Nigeria. Water Air Soil Pollut 86:13-34

Conde M, Le Billon P (2017) Why do some communities resist mining projects while others do not? Extr Ind Soc 4:681-697

Eaton AD, Clesceri LS, Greenberg AE (1995) Standard methods for the examination of water and wastewater, 19th edn. American Public Health Association, Washington

Engels B, Dietz K (2017) Contested extractivism. Society and the state: struggles over mining and land. Springer, New York

Ezeaku PI (2012) Evaluating the influence of open cast mining of solid minerals on soil, landuse and livelihood systems in selected areas of Nasarawa State, north-central Nigeria. J Ecol Nat Environ 4(3):62-70

Ezeh HN (2007) Environmental significance of heavy metals distribution in the Ebonyi river drainage system, Abakaliki and Ohaozara Areas, South Eastern Nigeria. Ph.D. Thesis, Nnamdi Azikiwe University, Awka, Nigeria, p 214

Ezeh HN, Anike OL (2009) The preliminary assessment of the pollution status of streams and artificial lakes created by mining in the mining district of Enyigba, south eastern Nigeria, and their consequences. Glob J Environ Sci 8(1):41-48

Fakayode SO, Olu-Owolobi BI (2003) Heavy metal contamination of roadside topsoil in Oshogbo, Nigeria: its relationship to traffic density and proximity to highways. J Environ Geol 4(2):150-157

Federal Department of Agriculture Land Resources (FDALR) (1985) Reconnaissance soil survey of Anambra State of Nigeria. Soil reports 1985. (FDALR) Lagos, Nigeria

Gamu J, Le Billon P, Spiegel S (2015) Extractive industries and poverty: a review of recent findings and linkage mechanisms. Extract Ind Soc 2(1):162-176
Goel PK (2006) Water pollution: causes, effects and control. New Delhi, New age International, p 179. ISBN 978-81-224-1839-2

Haddis A, Getahun T, Mengistie E, Jemal A, Smets I, Bruggen B (2014) Challenges to surface water quality in mid-sized African cities: conclusions from Awetu-Kito Rivers in Jimma, south-west Ethiopia. Water Environ J 28:173-182

Hogan MC (2010) Water pollution. Encyclopedia of Earth. Ed. Mark McGinley (ed) In Chief C. Cleveland. National Council on Science and the Environment, Washington, D.C.

Hoiberg DH (2010) Abakaliki. Encyclopaedia Britannica. 1: A-ak Bayes (15th ed.). Encyclopaedia Britannica, Inc, Chicago. ISBN 0-85229-961-3

Ibetao CN, Okoye COB (2010) High levels of heavy metals in blood of urban population in Nigeria. Res J Environ Sci 4(4):371-382

INECE (International Network for Environmental Compliance and Enforcement) (2016) Mining support package: metallic ores and minerals. http://www.inece.org/PDFDocs/mining.pdf. Accessed 10 Mar 2016

Kabata-Pendias A, Pendias H (2001) Trace elements in soils and plants, 3rd edn. CRC Press, Boca Raton, p 413

Khan S, Shahanza M, Jehan N, Rehman S, Shah MT, Din I (2013) Drinking water quality and human health risk in Charsadda district, Pakistan. J Clean Prod 60:93-101

Kirsch S (2014) Mining capitalism: the relationship between corporations and their critics. University of California Press, Berkeley

Kramer KJM (1994) Inorganic contaminants in the water column: sampling and sampling strategy. Int J Environ Anal Chem 5:179-188

Krausmann F, Gingrich S, Eisenmenger N, Erb KH, Haberl H, FischerKowalski M (2009) Growth in global materials use: GDP and population during the 20th century. Ecol Econ 68:2696-2705

Kribek B (2013) Recommendations for the collection and processing of samples when assessing the degree and extent of contamination of surface and ground waters, stream sediments, soils, and vegetation in areas affected by mining and mineral processing in countries of Sub-Saharan Africa. Unpublished report. SIDA Project Planning Meeting, 2013. Prague, Czech Republic. pp 1-6

Lghoul M, Maqsoud A, Hakkou R, Kchikach A (2014) Hydrogeochemical behavior around the abandoned Kettara mine site, Morocco. J Geochem Explor 144:456-467

Louw H, Marais L (2018) Mining and municipal finance in Kathu, an open mining town in South Africa. Extr Ind Soc 5(3):278-283

Marcovecchio JE, Botte SE, Freije RH (2007) Heavy metals, major metals, trace elements. In: Nollet LM (ed) Handbook of water analysis, 2nd edn. CRC Press, London, pp 275-311

Martinez Alier J (2003) The environmentalism of the poor: a study of ecological conflicts and valuation. Edward Elgar Publishing, Cheltenham

Martinez Alier J, Anguelovski I, Bond P, Del Bene D, Demaria F, Gerber JF, Greyl L, Haas W, Healy H, Marín-Burgos V, Ojo G, Firpo Porto M, Rijnhout L, Rodríguez-Labajos B, Spangenberg J, Temper L, Warlenius R, Yánez I (2014) Between activism and science: grassroots concepts for sustainability coined by environmental justice organizations. J Polit Ecol 21:19-60

McCarthy TS (2011) The impact of acid mine drainage in South Africa. S Afr J Sci 107(5/6):7. https://doi.org/10.4102/sajs.v107i5/6.712

McDonald R, Douglas I, Grimm N, Hale R, Revenga C, Gronwall J, Fekete B (2011a) Implications of fast urban growth for freshwater provision. Ambio 4:437

McDonald R, Green P, Balk D, Fekete B, Revenga C, Tod M, Montgomery M (2011b) Urban growth, climate change, and freshwater availability. Proc Natl Acad Sci 108:6312-6317

Mclean EO (1982) Soil pH and lime requirement. In: Page AL (ed) Methods of soils analysis. Part 2. Agronomy monograph, vol 9. ASA and SSS, Madison, pp 199-224 
Mhlongo M, Mativenga PT, Marnewick A (2018) Water quality in a mining and water-stressed region. J Clean Prod 171:446-456

Montouris A, Voutsas E, Tassios D (2002) Bioconcentration of heavy metals in aquatic environments: the importance of bioavailability. Mar Pollut Bull 44:1136-1141

Mouratiadou I, Biewald A, Pehl M, Bonsch M, Baumstark L, Klein D, Popp A, Luderer G, Kriegler E (2016) The impact of climate change mitigation on water demand for energy and food: an integrated analysis based on the shared socioeconomic pathways. Environ Sci Policy 64:48-58

Navarro MC, Pérez-Sirvent C, Martínez-Sánchez MJ, Vidal J, Tavar PJ, Bech J (2008) Abandoned mine sites as a source of contamination by heavy metals - a case study in a semi-arid zone. $\mathrm{J}$ Geochem Explor 96(2-3):183-193

Ngele SO, Itumoh EJ, Obini U (2015) Evaluation of metal contaminants of surface water sources in an active $\mathrm{Pb}-\mathrm{Zn}$ mine pit and a nearby pond: comparison of levels of contamination. Global $\mathbf{J}$ Pure Appl Sci 21(1):93-96

Nnabo PN (2015a) Heavy metal contamination in soils in Enyigba $\mathrm{Pb}-\mathrm{Zn}$ mines district, Southeastern Nigeria using metal enrichment and pollution indices. Int J Res Environ Sci 2:48-59

Nnabo PN (2015b) Assessment of contamination of underground water sources in Enyigba $\mathrm{Pb}-\mathrm{Zn}$ district, southeastern Nigeria using metal enrichment and pollution indices. Int J Sci 4:46-57

Nnabo PN (2015c) Assessment of heavy metal contamination of water sources from Enyigba $\mathrm{Pb}-\mathrm{Zn}$ district Southeastern Nigeria. Int J Sci Technol Res 4(9):187-197

Nnabo PN (2016) Surface water contamination by heavy metals from Enyigba $\mathrm{Pb}-\mathrm{Zn}$ mine district, Southeastern Nigeria using metal enrichment and pollution indices. Int J Sci Technol 5(1):8-18

Northey SA, Mudd GM, Saarivuori E (2016) Water footprinting and mining: where are the limitations and opportunities? J Clean Prod 135:1098-1116

Nweke FN, Okaka ANC, Offor EC (2008) Lead, zinc and pH concentrations in Enyigba soils in Abakaliki local government area of Ebonyi State, Nigeria. Afr J Biotechnol 7(14):2441-2443

Obiora SC, Umeji AC (2004) Petrographic evidence for regional burial metamorphism of the sedimentary rocks in the lower benue rift. J Afr Earth Sci 38:269-277

Obiora SC, Chukwu A, Davies TC (2016) Heavy metals and health risk assessment of arable soils and food crops around $\mathrm{Pb}-\mathrm{Zn}$ mining localities in Enyigba, Southeastern Nigeria. J Afr Earth Sc 116:182-189

Ogwueleka TC (2015) Use of multivariate statistical techniques for the evaluation of temporal and spatial variations in water quality of the Kaduna River, Nigeria. Environ Monit Assess 187:137

Okogbue CO, Ukpai SN (2013) Geochemical evaluation of groundwater quality in Abakaliki area, Southeast Nigeria. Jordan J Earth Environ Sci 5(1):1-8

Okolo CC (2014) Impact of solid minerals mining on selected soil and water properties in Enyigba, Ebonyi State, Nigeria. Unpublished M.Sc Dissertation. Department of Soil Science, University of Nigeria, Nsukka

Okolo CC, Ezeaku PI, Nwite JN, Mbah CN, Anikwe MAN (2013) Environmental and agronomic implication of the levels of heavy metal concentration of soils along Enugu-Abakaliki major highway in southeastern Nigeria. Elixir Agric 61:17040-17046

Okolo CC, Akamigbo FOR, Ezeaku PI, Nwite JN, Nwite JC, Ezeudo VC, Ene J, Ukaegbu EP, Udegbunam ON, Eze NC (2015) Impact of open cast mine land use on soil physical properties in Enyigba, South-eastern Nigeria and the implication for sustainable land use management. Nigerian J Soil Sci 25(1):95-101
Olajire AA, Imeokparia FE (2001) Water quality of Osun River: studies on inorganic nutrients. Environ Monit Assess 69:17-28

Omaka ON, Aghamelu OP, Ike-Amadi CA, Ofoezie RC (2017) Assessment of the quality of groundwater from different parts of southeastern Nigeria for potable use. Environ Earth Sci $76: 344$

O'Neill A, Phillips DH, Bowena J, Gupta BS (2015) Contaminants in surface water and sediments near the Tynagh silver mine site, County Galway, Ireland. Sci Total Environ 512-513:261-272

Oparaocha ET, Iroegbu OC, Obi RK (2010) Assessment of quality of drinking water sources in the Federal University of Technology, Owerri, Imo State, Nigeria. J Appl Biosci 32:1964-1976

Oriji JN (2011) Political organization in Nigeria since the last stone age: a history of the Igbo People. Palgrave Macmillan, New York. ISBN 978-0-230-62193-0

Overseas Development of Natural Resources Institute (ODNRI) (1989) Nigeria profile of agricultural potential. ODA, Chatham

Oyedotun TDT (2012) Urban water usages in Egbeda area of Oyo State, Nigeria. In: Proceeding of world wide workshop for young environmental scientists, WWWYES, 2012 tagged "urban waters: resource or risk?" Arcueil, France; 20-26 May, 2012, pp 155-165. doi:hal-00709630

Rakotondrabe F, Ngoupayou JRN, Mfonka Z, Rasolomanana EH, Abolo AJN, Ako AA (2018) Water quality assessment in the Bétaré-Oya gold mining area (East-Cameroon): multivariate statistical analysis approach. Sci Total Environ 610-611:831-844

Rasool A, Xiao T, Farooqi A, Shafeeque M, Masood S, Ali S, Fahad S, Nasim W (2016) Arsenic and heavy metal contaminations in the tube well water of Punjab, Pakistan and risk assessment: a case study. Ecol Eng 95:90-100

Scanlon T, Uguru OP, Jafry T, Chinsinga B, Mvula P, Chunga J, Zimba ML, Mwape M, Nyundo L, Mwiinga B, Chungu K (2016) The role of social actors in water access in Sub-Saharan Africa: evidence from Malawi and Zambia. Water Resour Rural Dev 8:25-36

SDWF (2010) Safe drinking water foundation: water consumption. www.safewater.org/PDFS/resourcesknownfacts/waterconsu mption.pdf. Accessed 08 Feb 2016

Seccatore J, Veiga M, Origliasso C, Marin T, De Tomi G (2014) An estimation of the artisanal small-scale production of gold in the world. Sci Total Environ 496:662-667

Segura R, Arancibia V, Zuniga MC, Pasten P (2006) Distribution of copper, zinc, lead and cadmium concentrations in stream sediments from the Mapocho River in Santiago, Chile. J Geochem Explor 91:71-80

Sekabira K, Origa HO, Basamba TA, Mutumba G, Kakudidi E (2010) Assessment of heavy metal pollution stream sediments and its tributaries. Int J Environ Sci Technol 7:435-446

Seth R, Mohan M, Singh P, Singh R, Dobhal R, Singh KP, Gupta $S$ (2016) Water quality evaluation of Himalayan Rivers of Kumaun region, Uttarakhand, India. Appl Water Sci 6:137-147

Suresh G, Sutharsan P, Ramasamy V, Venkatachalapathy R (2012) Assessment of spatial distribution and potential ecological risk of the heavy metals in relation to granulometric contents of Veeranam lake sediments, India. Ecotoxicol Environ Saf $84: 117-124$

Taiwo AM, Awomeso JA (2017) Assessment of trace metal concentration and health risk of artisanal gold mining activities in Ijeshaland, Osun State Nigeria_-part 1. J Geochem Explor 177:1-10

Tang W, Zhao Y, Wang C, Shan B, Cui J (2013) Heavy metal contamination of overlying waters and bed sediments of Haihe Basin in China. Ecotoxicol Environ Saf 98:317-332 
Tsado PA, Lawal BA, Eze PC, Afolabi SG, Saidu OI, Igwe CA (2014) Assessment of the suitability of water quality for irrigation in Minna, Niger State. Int J Res Agric For 1(2):13-17

Uguru OP (2014) Improving access to water and sanitation via effective community engagement: study of urban Abakaliki. Glasgow Caledonian University, Scotland, Nigeria

UNEP (2008) Vital water graphics. An overview of the state of the world's fresh and marine waters, 2nd edn. United Nations Environment Programme, New York

Waseem A, Arshad J, Iqbal F, Sajjad A, Mehmood Z, Murtaza G (2014) Pollution status of Pakistan: a retrospective review on heavy metal contamination of water, soil, and vegetables. Biomed Res Int 2014:29. https://doi.org/10.1155/2014/813206

Watts M (2015) Securing oil. Frontiers, risk and spaces of accumulated insecurity. In: Apppel H, Mason A, Watts M (eds) Subterranean estates: life worlds of oil and gas. Cornell University Press, Ithaca, pp 210-236

WHO (World Health Organisation) (2011) Guidelines for drinking water quality, vol 1, 4th edn. World Health Organisation, Geneva
WHO (World Health Organisation) (2014) The top 10 causes of death. Fact sheet no 310. Updated May 2014. http://www.who. int/mediacentre/factsheets/fs310/en/. Accessed 9 Mar 92016

Wu Q, Zhou H, Tam NFY, Tian Y, Tan Y, Zhou S, Li Q, Chen Y, Leung JYS (2016) Contamination, toxicity and speciation of heavy metals in an industrialized urban river: implications for the dispersal of heavy metals. Mar Pollut Bull 104:153-161

Yang C, Lu G, Chen M, Xie Y, Guo C, Reinfelder J, Yi X, Wang H, Dang Z (2016) Spatial and temporal distributions of sulfur species in paddy soils affected by acid mine drainage in Dabaoshan sulfide mining area, South China. Geoderma 281:21-29

Zhu T, Ringler C (2010) Climate change implications for water resources in the Limpopo River Basin, IFPRI discussion papers 961, International Food Policy Research Institute (IFPRI)

Publisher's Note Springer Nature remains neutral with regard to jurisdictional claims in published maps and institutional affiliations. 